\title{
Marinitoga hydrogenitolerans sp. nov., a novel member of the order Thermotogales isolated from a black smoker chimney on the Mid-Atlantic Ridge
}

\author{
Correspondence \\ Anne Postec \\ Anne.Postec@ifremer.fr
}

\author{
Anne Postec, ${ }^{1}$ Claire Le Breton, ${ }^{1}$ Marie-Laure Fardeau, ${ }^{2}$ \\ Françoise Lesongeur, ${ }^{1}$ Patricia Pignet, ${ }^{1}$ Joël Querellou, ${ }^{1}$ \\ Bernard Ollivier ${ }^{2}$ and Anne Godfroy ${ }^{1}$
}

\author{
${ }^{1}$ Laboratoire de Microbiologie et de Biotechnologie des Extrêmophiles, IFREMER, Centre de \\ Brest, BP 70, 29280 Plouzané, France \\ ${ }^{2}$ Laboratoire IRD de Microbiologie des Anaérobies, UR 101, Universités de Provence et de la \\ Méditerranée, CESB-ESIL, case 925, 163 avenue de Luminy, 13288 Marseille, France
}

\begin{abstract}
A novel, thermophilic, anaerobic bacterium that is able to tolerate hydrogen was isolated from a deep-sea hydrothermal chimney collected at the Rainbow field on the Mid-Atlantic Ridge. Cells were rod-shaped and surrounded by a sheath-like outer structure (toga); they were weakly motile by means of a polar flagellum. They appeared singly, in pairs or in short chains.

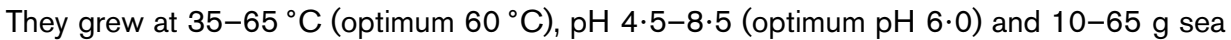
salts $\mathrm{I}^{-1}$ (optimum 30-40 $\mathrm{g} \mathrm{I}^{-1}$ ). The isolate was organotrophic, and able to grow on various carbohydrates or complex proteinaceous substrates. Growth was not inhibited under $100 \%$ hydrogen or in the presence of $2 \%$ oxygen in the gas phase. The isolate reduces sulfur, although sulfur reduction is not required for growth. The fermentation products identified on glucose were acetate, ethanol, formate, hydrogen and $\mathrm{CO}_{2}$. The $\mathrm{G}+\mathrm{C}$ content of the genomic DNA was $28 \pm 1 \mathrm{~mol} \%$. Phylogenetic analysis of the 16S rRNA gene placed the strain within the genus Marinitoga, order Thermotogales, in the bacterial domain. On the basis of the 16S rRNA gene sequence comparisons and physiological characteristics, the isolate is considered to represent a novel species, for which the name Marinitoga hydrogenitolerans sp. nov. is proposed. The type strain is $\mathrm{AT}_{1271^{\top}}\left(=\mathrm{DSM} 16785^{\top}=\mathrm{JCM} 12826^{\top}\right)$.
\end{abstract}

The order Thermotogales comprises rod-shaped, Gramnegative, non-sporulating bacteria that have a loose surrounding membrane or 'toga'. They are anaerobic, organotrophic and thermophilic. These organisms have been isolated from a variety of environments, such as oil reservoirs, hot springs and marine hydrothermal vents (Antoine et al., 1997; Lien et al., 1998; Windberger et al., 1989). The order Thermotogales includes six genera: Thermotoga, Thermosipho, Fervidobacterium, Petrotoga, Geotoga and Marinitoga (Davey et al., 1993; Huber et al., 1986, 1989; Patel et al., 1985; Wery et al., 2001a). To date, only two species belonging to the genus Marinitoga have been described, Marinitoga camini (Wery et al., 2001a) and Marinitoga piezophila (Alain et al., 2002), both originating from deep-sea hydrothermal vents. Members of the order Thermotogales are fermentative bacteria that produce hydrogen, the accumulation of which has been widely

Published online ahead of print on 7 January 2005 as DOI 10.1099/ ijs.0.63550-0.

The GenBank/EMBL/DDBJ accession number for the 16S rRNA gene sequence of $A T 1271^{\top}$ is $A J 786363$. reported to inhibit their growth (Van Ooteghem et al., 2002). This inhibition could be overcome by addition of elemental sulfur or thiosulfate (Alain et al., 2002; Antoine et al., 1997; Jeanthon et al., 1995; Lien et al., 1998). Here we report the description of a novel thermophilic bacterium belonging to the genus Marinitoga that is able to tolerate $100 \%$ hydrogen in the headspace when growing on organic substrates.

Samples were collected by the ROV Victor in 2001 during the ATOS cruise on the Mid-Atlantic Ridge. The deep-sea vent field Rainbow $\left(36^{\circ} 13^{\prime} \mathrm{N} 33^{\circ} 54^{\prime} \mathrm{W}\right)$ at $2275 \mathrm{~m}$ depth was explored and part of an active black smoker chimney was brought to the surface in a decontaminated insulated box. On board, eight subsamples representative of the whole chimney were crushed in an anaerobic chamber and stored in sterile serum vials filled with sterile sea water containing $0.5 \mathrm{mg} \mathrm{Na}_{2} \mathrm{~S} \mathrm{l}^{-1}$. The subsamples were pooled and used as inoculum at $2 \%(\mathrm{v} / \mathrm{v})$. A continuous enrichment culture was performed on a modified SME medium (Postec et al., 2005; Sharp \& Raven, 1997) in a 2 litre gas-lift bioreactor (Godfroy et al., 2000; Raven et al., 1992) at $60^{\circ} \mathrm{C}$ at 
atmospheric pressure. A culture sample collected on day 7 permitted the isolation of several strains by three serial dilutions to extinction (Baross, 1995). Single colonies were obtained by streaking on the same medium solidified with $15 \mathrm{~g}$ Gelrite $^{-1}$ (Scott Laboratories). Plates were incubated for 2 days at $60^{\circ} \mathrm{C}$ in anaerobic jars (Godfroy et al., 1997). Colonies were subsequently picked and streaked twice under the same conditions. One isolate was referenced as strain AT $1271^{\mathrm{T}}$ and was chosen for further characterization.

Microscopic observations indicated that cells of isolate AT1271 ${ }^{\mathrm{T}}$ were weakly motile rods surrounded by a 'toga', an outer sheath-like structure. Cells were approximately $0.6 \mu \mathrm{m}$ wide and $1.5 \mu \mathrm{m}$ long during the exponential phase and appeared single or in short chains within the envelope. Cells became elongated, forming long chains, during stationary phase (Fig. 1). Cells were negatively stained for examination under a transmission electron microscope (Raguénès et al., 1997): a polar flagellum and the presence of a toga were observed (Fig. 1). The Ryu $\mathrm{KOH}$ reaction (Powers, 1995) leading to immediate cell lysis, as confirmed by phase-contrast microscopy, was positive, indicating that cells of strain AT $1271^{\mathrm{T}}$ were Gram-negative.

The new isolate was routinely grown on GYPS medium containing (per litre): $5 \mathrm{~g}(+)$-D-glucose (Sigma), $0.5 \mathrm{~g}$ yeast extract (Difco), $1 \mathrm{~g}$ bacto-peptone (Difco), $30 \mathrm{~g}$ sea salts (Sigma), $3.9 \mathrm{~g}$ MES buffer (Sigma) and $0 \cdot 1 \%(\mathrm{v} / \mathrm{v})$ resazurin solution. The $\mathrm{pH}$ was adjusted to $6 \cdot 0$ before autoclaving for $20 \mathrm{~min}$ at $121^{\circ} \mathrm{C}$. The medium was reduced

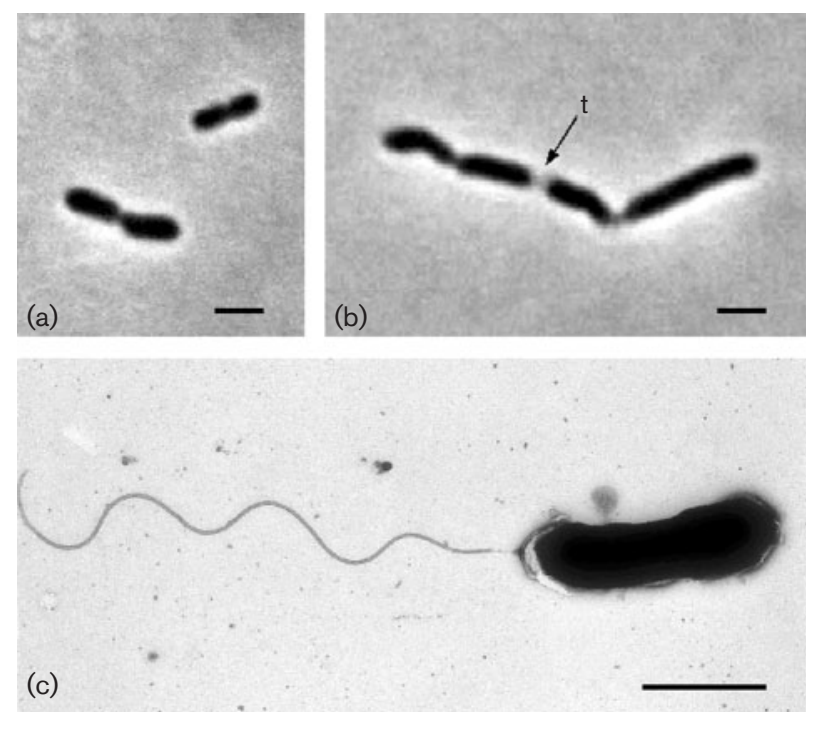

Fig. 1. (a, b) Phase-contrast micrographs of strain $A T 1271^{\top}$. (a) Rod-shaped cells in the mid-exponential phase of growth, dividing by constriction; bar, $1 \mu \mathrm{m}$. (b) Cells in a chain surrounded by a sheath-like structure or 'toga' (t); bar, $1 \mu \mathrm{m}$. (c) Electron micrograph of a negatively stained cell showing the polar flagellum; bar, $1 \mu \mathrm{m}$. by addition of $0.5 \mathrm{~g} \mathrm{Na}_{2} \mathrm{~S}$ before inoculation. Cultures were incubated under anaerobic conditions, $\mathrm{N}_{2} / \mathrm{H}_{2} / \mathrm{CO}_{2}$ (90:5:5), at atmospheric pressure. All experiments were performed in triplicate. Methods for the determination of growth parameters was as described by Wery et al. (2001b). Bacterial growth was directly monitored in culture tubes by spectrometry at $600 \mathrm{~nm}$ (a Spectronic 401 instrument; Milton Roy). Previous correlation between the optical density at $600 \mathrm{~nm}$ and cell numeration was simultaneously established by direct counting of the cells using a Thoma chamber viewed with an Olympus model BH-2 microscope. Isolate $\mathrm{AT} 1271^{\mathrm{T}}$ grew at $35-65^{\circ} \mathrm{C}$; the optimum temperature was $60^{\circ} \mathrm{C}$. Growth occurred at $\mathrm{pH} 4 \cdot 5-8 \cdot 5$, the optimum being around $\mathrm{pH} 6$. No growth was observed at $\mathrm{pH} 4$ or $\mathrm{pH}$ 9. The strain grew at sea salt concentrations ranging from 10 to $65 \mathrm{~g} \mathrm{l}^{-1}$ (corresponding to $8-50 \mathrm{~g} \mathrm{NaCl}$ $1^{-1}$ ). The optimum sea salt concentration for growth was approximately $35 \mathrm{~g} \mathrm{l}^{-1}$ (corresponding to $27 \mathrm{~g} \mathrm{NaCl} \mathrm{l}^{-1}$ ). Under optimal conditions, the maximal cell density

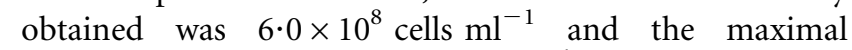
observed growth rate was $0.37 \mathrm{~h}^{-1}$ (equivalent to a doubling time of $1.9 \mathrm{~h}$ ).

Strain $\mathrm{AT} 1271^{\mathrm{T}}$ is an obligate chemo-organotroph. No growth was detected on mineral media complemented with a $\mathrm{H}_{2} / \mathrm{CO}_{2}(80: 20)$ headspace. The ability of the isolate to use various carbon sources was tested in medium containing (per litre): $30 \mathrm{~g}$ sea salts, $3.9 \mathrm{~g}$ MES buffer, $10 \mathrm{ml}$ vitamin solution (Balch et al., 1979), $10 \mathrm{ml}$ mineral solution (Balch et al., 1979), $0 \cdot 1 \mathrm{~g}$ yeast extract as the nitrogen source and complex carbon sources. The following carbohydrates were tested at $0.5 \%(\mathrm{w} / \mathrm{v})$ : cellobiose, glucose, maltose, fructose, galactose, ribose, starch, cellulose, glycogen, chitin, pectin and carboxymethylcellulose. Ethanol was tested at $0.5 \%(\mathrm{v} / \mathrm{v})$. The following organic acids and proteinaceous substrates were tested at $0 \cdot 2 \%(\mathrm{w} / \mathrm{v})$ : acetate, pyruvate, yeast extract, brain heart infusion, peptone, tryptone, casein, Casamino acids and keratin. A solution of 20 amino acids, each at $0 \cdot 1 \mathrm{~g} \mathrm{l}^{-1}$, was also tested. Positive cultures were confirmed by subcultures on the same medium. Compared with growth on the medium without added carbon source, growth was enhanced by addition of glucose, starch, glycogen, chitin, yeast extract, brain heart infusion, peptone and casein. To extend the investigation of carbohydrate consumption, cellobiose, glucose, maltose, fructose, galactose, ribose, acetate, pyruvate and rhamnose were tested at $1 \mathrm{~g} \mathrm{l}^{-1}$ in the presence $1 \mathrm{~g}$ yeast extract $1^{-1}$. A negative control was performed without added sugar. Growth was monitored by spectrometry and carbohydrate concentrations were estimated by HPLC after 6 and $13 \mathrm{~h}$ of culture. At these conditions, growth of strain $\mathrm{AT} 1271^{\mathrm{T}}$ was enhanced when pyruvate or maltose was added. Nitrogen sources were tested in medium containing (per litre): $30 \mathrm{~g}$ sea salts, $3.9 \mathrm{~g}$ MES buffer, $10 \mathrm{ml}$ Balch vitamins, $10 \mathrm{ml}$ mineral solution and glucose $\left(5 \mathrm{~g} \mathrm{l}^{-1}\right)$. Growth occurred in the presence of yeast extract $\left(0 \cdot 2 \mathrm{~g} \mathrm{l}^{-1}\right)$, whereas urea $\left(0 \cdot 2 \mathrm{~g} \mathrm{l}^{-1}\right)$ and $\mathrm{NH}_{4} \mathrm{Cl}\left(1 \mathrm{~g} \mathrm{l}^{-1}\right)$ alone did not support growth. 
The end-products of glucose metabolism were acetate, ethanol, formate, hydrogen and $\mathrm{CO}_{2}$. In the presence of elemental sulfur, no hydrogen was detected. Growth in the presence of different electron acceptors was tested on GYPS medium. A small increase in the final cell concentration was obtained when thiosulfate $(20 \mathrm{mM})$, cystine $(50 \mathrm{mM})$ or sulfur $\left(10 \mathrm{~g} \mathrm{l}^{-1}\right)$ was added. Addition of sulfate $(20 \mathrm{mM})$, sulfite $(1 \mathrm{mM})$, nitrate $(20 \mathrm{mM})$ or nitrite $(1 \mathrm{mM})$ did not enhance growth. Strong production of $\mathrm{H}_{2} \mathrm{~S}$ was revealed by using lead acetate strips (Whatman) on the culture with cystine and sulfur, indicating the use of these electron acceptors.

Various gas phases were tested in the presence and absence of sulfur $\left(10 \mathrm{~g} \mathrm{l}^{-1}\right)$ on GYPS medium: $\mathrm{N}_{2} / \mathrm{H}_{2} / \mathrm{CO}_{2}$ (90:5:5), $\mathrm{H}_{2} / \mathrm{CO}_{2}(80: 20), \mathrm{N}_{2} / \mathrm{CO}_{2}(80: 20)$ and $\mathrm{N}_{2}$ $(100 \%)$. Cell density was above $1 \times 10^{8} \mathrm{ml}^{-1}$ in the absence of sulfur, and above $4 \times 10^{8} \mathrm{ml}^{-1}$ in the presence of sulfur, regardless of the gas phase.

The effect of $\mathrm{H}_{2}$ in the gas phase was tested using the following $\mathrm{N}_{2} / \mathrm{H}_{2}$ ratios: $100: 0,80: 20,60: 40,40: 60,20: 80$ and $0: 100$. M. camini, M. piezophila and strain AT1271 ${ }^{\mathrm{T}}$ were grown for comparison in triplicate on GYPS at 50, 65 and $60{ }^{\circ} \mathrm{C}$, respectively. The initial gas phase of the culture medium $\left(\mathrm{N}_{2} / \mathrm{H}_{2} / \mathrm{CO}_{2} 90: 5: 5\right)$ was replaced and 10 cycles of vacuum extraction/addition of the different calibrated mixtures of $\mathrm{N}_{2} / \mathrm{H}_{2}$ were performed. Cell densities were estimated after 4, 8, 12 and 24 h of incubation by counting. No significant difference appeared between controls made with $\mathrm{N}_{2} / \mathrm{H}_{2} / \mathrm{CO}_{2}(90: 5: 5)$. Maximal cell concentrations for M. camini and M. piezophila were obtained with $0 \% \mathrm{H}_{2}$. Congruently, no growth was observed for either species with $80 \% \mathrm{H}_{2}$ (Alain et al., 2002; Wery et al., 2001a). M. camini and $M$. piezophila displayed a linear decrease in maximal cell concentration with $\mathrm{H}_{2}$ increase, and total inhibition of growth at 40 and $60 \% \mathrm{H}_{2}$, respectively. In contrast, strain AT1271 ${ }^{\mathrm{T}}$ grew at up to $2-4 \times 10^{8}$ cells $\mathrm{ml}^{-1}$ regardless of $\mathrm{H}_{2}$ concentration. Strain AT1271 ${ }^{\mathrm{T}}$ tolerates up to $2 \%$ oxygen in the gas phase. Growth was inhibited in the presence of $4 \%$ oxygen.

Genomic DNA was extracted as described by Wery et al. (2001a). The $\mathrm{G}+\mathrm{C}$ content was determined by thermal denaturation (Marmur \& Doty, 1962) with the modifications described by Raguénès et al. (1997). The $\mathrm{G}+\mathrm{C}$ content of the genomic DNA of strain AT1271 ${ }^{\mathrm{T}}$ was $28 \pm 1 \mathrm{~mol} \%$. The $16 \mathrm{~S}$ rRNA gene was selectively amplified as described by Wery et al. (2001b), and the PCR product was sequenced with the primers described by Raguénès et al. (1996). The sequence was then compared with available sequences in the GenBank database using a BLAST search (Altschul et al., 1990). A multiple sequence file was obtained by using the Wisconsin Package version 10.3 (Accelrys Inc.). Alignments and similarity levels were obtained by the CLUSTAL W method with weighted residues (Thompson et al., 1994). Alignments were manually refined using the multiple sequence alignment editor SEAVIEW and the phylogenetic reconstruction was produced using PHYLO_WIN (Galtier et al., 1996) with the following algorithms: Jukes-Cantor distance matrix and successively the neighbour-joining (Saitou \& Nei, 1987), maximum-parsimony and maximumlikelihood methods (Felsenstein, 1981). Bootstrap values (Felsenstein, 1985) were determined. Strain AT1271 ${ }^{\mathrm{T}}$ was phylogenetically affiliated to the genus Marinitoga (Fig. 2), the nearest recognized relatives being $M$. camini and $M$. piezophila with respective 16S rRNA gene sequence similarities of 96 and $94 \%$. The positioning of strain AT $1271^{\mathrm{T}}$ was supported by the results of the three algorithms used.

The characteristics of strain AT1271 ${ }^{\mathrm{T}}$ are consistent with its assignment to the order Thermotogales. On the basis of the results of $16 \mathrm{~S}$ rRNA gene sequence analysis, the new isolate is most closely related to M. camini, the first species described among the genus Marinitoga. M. camini and strain $\mathrm{AT} 127 \mathrm{1}^{\mathrm{T}}$ both originated from the Mid-Atlantic Ridge. However, strain $\mathrm{AT} 1271^{\mathrm{T}}$ can be distinguished from M. camini based on phylogenetic and phenotypic criteria: the two share $96 \%$ 16S rRNA gene sequence similarity. Also, in comparison with $M$. camini, the $\mathrm{pH}$ range and $\mathrm{pH}$ optimum for the new isolate were lower and optimum $\mathrm{NaCl}$ concentration for growth was higher (30-40 versus $20 \mathrm{~g} \mathrm{l}^{-1}$ ) (Table 1). Moreover, unlike M. camini, strain AT1271 ${ }^{\mathrm{T}}$ does not use sucrose, fructose, cellobiose, cellulose, carboxymethylcellulose or pectin, and it does ferment casein. It is noteworthy that strain $\mathrm{AT}_{12} 21^{\mathrm{T}}$ tolerates $100 \%$ hydrogen in the gas phase whereas the growth of other Marinitoga species is inhibited at lower hydrogen concentrations. This tolerance to hydrogen has never been reported to date among the order Thermotogales, and could be related to the high hydrogen concentrations measured $\left(16 \mathrm{mmol} \mathrm{kg}^{-1}\right)$ in all vent fluids at the Rainbow field,

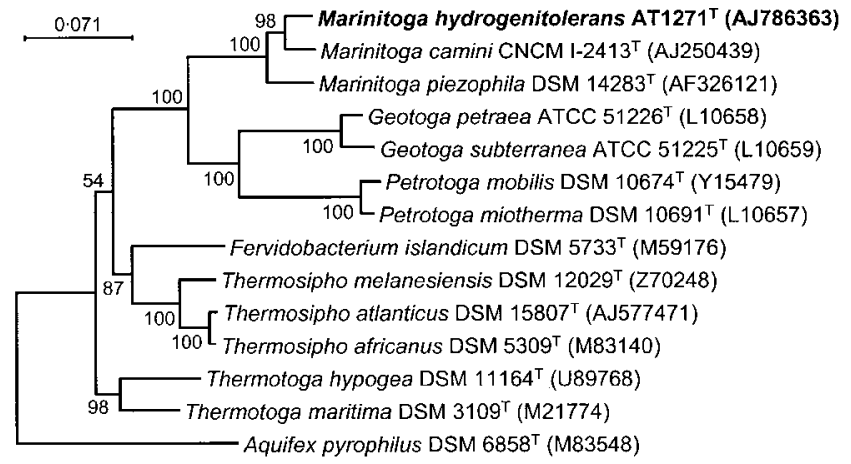

Fig. 2. Phylogenetic position of strain $A T 1271^{\top}$ within the order Thermotogales based on 16S rRNA gene sequences. A total of 1351 sites were used for the phylogenetic analysis. Accession numbers and type strains are indicated. The topology shown corresponds to an unrooted tree obtained by a neighbour-joining algorithm (Jukes-Cantor corrections) established using PHYLO_WIN and manually refined using SEAVIEW. Bootstrap values are displayed on their respective branches. Bar, $7 \cdot 1$ nucleotide substitutions per 100 nucleotides. 
Table 1. Characteristics used to differentiate members of the genus Marinitoga

+ , Positive, - , negative; $(+)$, weakly positive; ND, not determined. Substrates were tested in the presence of $0 \cdot 1 \mathrm{~g}$ yeast extract $1^{-1}$, except M. piezophila $\left(0 \cdot 2 \mathrm{~g}^{-1}\right)$. All three type strains were isolated from hydrothermal vents: EPR, East-Pacific Ridge; MAR, Mid-Atlantic Ridge.

\begin{tabular}{|c|c|c|c|}
\hline Characteristic & M. camini MV1075 & M. piezophila $\mathrm{KA3}^{\mathrm{T}}$ & $\operatorname{AT} 1271^{\mathrm{T}}$ \\
\hline Reference & Wery et al. (2001a) & Alain et al. (2002) & This study \\
\hline Origin & $\begin{array}{l}\text { MAR, Menez-Gwen site } \\
\left(37^{\circ} 51^{\prime} \mathrm{N} 31^{\circ} 31^{\prime} \mathrm{W}\right)\end{array}$ & $\begin{array}{l}\text { EPR, Grandbonum site } \\
\left(12^{\circ} 48^{\prime} \mathrm{N} 103^{\circ} 56^{\prime} \mathrm{W}\right)\end{array}$ & 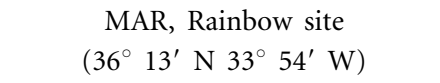 \\
\hline Motility & + & + & $(+)$ \\
\hline \multicolumn{4}{|l|}{$\mathrm{pH}$ for growth } \\
\hline Range & $5-9$ & $5-8$ & $4 \cdot 5-8 \cdot 5$ \\
\hline Optimum & 7 & 6 & 6 \\
\hline \multicolumn{4}{|l|}{ Temperature for growth $\left({ }^{\circ} \mathrm{C}\right)$} \\
\hline Range & $25-65$ & $45-70$ & $35-65$ \\
\hline Optimum & 55 & 65 & 60 \\
\hline \multicolumn{4}{|c|}{$\mathrm{NaCl}$ concentration for growth $\left(\mathrm{g} \mathrm{l}^{-1}\right)$} \\
\hline Range & $10-45$ & $10-50$ & $10-65$ \\
\hline Optimum & 20 & 30 & $30-40$ \\
\hline Optimal doubling time $(\mathrm{min})$ & 102 & 21 (at $40 \mathrm{MPa})$ & 112 \\
\hline \multicolumn{4}{|l|}{ Utilization of: } \\
\hline Casein & - & + & + \\
\hline Tryptone & + & + & - \\
\hline Casamino acids & - & + & - \\
\hline Fructose & $(+)$ & + & - \\
\hline Cellobiose & $(+)$ & + & - \\
\hline Galactose & - & + & - \\
\hline Ribose & - & $(+)$ & - \\
\hline Carboxymethylcellulose & + & ND & - \\
\hline Pectin & + & ND & - \\
\hline Cellulose & + & ND & - \\
\hline Glycogen & ND & - & + \\
\hline Pyruvate & + & - & + \\
\hline $\mathrm{H}_{2}$ inhibition & From $40 \% \mathrm{H}_{2}$ & From $60 \% \mathrm{H}_{2}$ & No inhibition \\
\hline Products of glucose fermentation & Acetate, $\mathrm{H}_{2}, \mathrm{CO}_{2}$ & $\mathrm{ND}$ & Acetate, ethanol, formate, $\mathrm{H}_{2}, \mathrm{CO}_{2}$ \\
\hline
\end{tabular}

the site from where strain AT $1271^{\mathrm{T}}$ was recovered (Charlou et al., 2002).

On the basis of its genetic and phenotypic characteristics, we propose that strain AT1271 ${ }^{\mathrm{T}}$ should be assigned to a novel species of the genus Marinitoga belonging to the Thermotogales. On the basis of its high tolerance to hydrogen, the name Marinitoga hydrogenitolerans sp. nov. is proposed.

\section{Description of Marinitoga hydrogenitolerans sp. nov.}

Marinitoga hydrogenitolerans (hy.dro.ge.ni.to'le.rans. N.L. hydrogenum hydrogen; L. pres. part. tolerans tolerating; N.L. adj. hydrogenitolerans hydrogen-tolerating, referring to its ability to tolerate a high level of hydrogen in the headspace).

Rod-shaped, weakly motile, Gram-negative bacteria surrounded by a sheath-like structure. Growth occurs at $35-65^{\circ} \mathrm{C}$ (optimum $60{ }^{\circ} \mathrm{C}$ ), $\mathrm{pH} 4 \cdot 5-8 \cdot 5$ (optimum pH 6•0) and $10-65 \mathrm{~g}$ sea salts $\mathrm{l}^{-1}$ (optimum 30-40 $\mathrm{g} \mathrm{l}^{-1}$ ). The doubling time under optimal conditions is $1.9 \mathrm{~h}$ and the maximum cell yield is $6 \cdot 0 \times 10^{8}$ cells $\mathrm{ml}^{-1}$. Anaerobic; resistant to concentrations of oxygen up to $2 \%$ and hydrogen up to $100 \%$. Chemo-organotrophic; able to ferment glucose, maltose, pyruvate, starch, glycogen, chitin, yeast extract, brain heart infusion, peptone and casein. Fermentation products identified on glucose are acetate, ethanol, formate, hydrogen and $\mathrm{CO}_{2}$. Sulfur, cystine and thiosulfate stimulate growth slightly and $\mathrm{H}_{2} \mathrm{~S}$ production is observed with sulfur and cystine. The $\mathrm{G}+\mathrm{C}$ content of the genomic DNA of the type strain is $28 \mathrm{~mol} \%$. $16 \mathrm{~S}$ rRNA gene sequence analysis indicates that the species is classified within the genus Marinitoga, order Thermotogales in the bacterial domain. 16S rRNA gene sequence similarity of the type strain to M. camini MV $1075^{\mathrm{T}}$ is $96 \%$.

The type strain, AT1271 ${ }^{\mathrm{T}}\left(=\mathrm{DSM} 16785^{\mathrm{T}}=\mathrm{JCM} 12826^{\mathrm{T}}\right)$, was isolated from a sample collected on the Rainbow

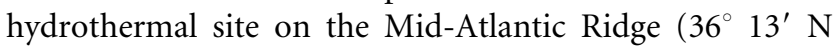
$\left.33^{\circ} 54^{\prime} \mathrm{W}\right)$. 


\section{Acknowledgements}

We wish to thank P. M. Sarradin, chief scientist of the ATOS cruise, as well as the captain and crew of the Atalante and the Victor team. We thank Mélusine Gaillard and Gérard Sinquin for their technical support with transmission electron microscopy. We thank Laurent Urios for helpful discussions. This work was supported by Ifremer, European VENTOX Program (EVK3-CT1999-2003) and Région Bretagne.

\section{References}

Alain, K., Marteinsson, V. T., Miroshnichenko, M. L., BonchOsmolovskaya, E. A., Prieur, D. \& Birrien, J. L. (2002). Marinitoga piezophila sp. nov., a rod-shaped, thermo-piezophilic bacterium isolated under high hydrostatic pressure from a deep-sea hydrothermal vent. Int J Syst Evol Microbiol 52, 1331-1339.

Altschul, S. F., Gish, W., Miller, W., Meyers, E. W. \& Lipman, D. J. (1990). Basic local alignment search tool. J Mol Biol 215, 403-410.

Antoine, E., Cilia, V., Meunier, J., Guezennec, J., Lesongeur, F. \& Barbier, G. (1997). Thermosipho melanesiensis sp. nov., a new thermophilic anaerobic bacterium belonging to the order Thermotogales, isolated from deep-sea hydrothermal vents in the southwestern Pacific Ocean. Int J Syst Bacteriol 47, 1118-1123.

Balch, W. E., Fox, G. E., Magrum, L. J., Woese, C. R. \& Wolfe, R. S. (1979). Methanogens: reevaluation of a unique biological group. Microbiol Rev 43, 260-296.

Baross, J. A. (1995). Isolation, growth and maintenance of hyperthermophiles. In Archaea: a Laboratory Manual, Thermophiles, pp. 15-23. Edited by F. T. Robb \& A. R. Place. Cold Spring Harbor, NY: Cold Spring Harbor Laboratory.

Charlou, J. L., Donval, J. P., Fouquet, Y., Jean-Baptiste, P. \& Holm, N. (2002). Geochemistry of high $\mathrm{H}_{2}$ and $\mathrm{CH}_{4}$ vent fluids issuing from ultramafic rocks at the Rainbow hydrothermal field $\left(36^{\circ} 14^{\prime} \mathrm{N}\right.$, MAR). Chem Geol 191, 345-359.

Davey, M. E., Wood, W. A., Key, R., Nakamura, K. \& Stahl, D. (1993). Isolation of three species of Geotoga and Petrotoga: two new genera, representing a new lineage in the bacterial line of descent distantly related to the 'Thermotogales'. Syst Appl Microbiol 16, 191-200.

Felsenstein, J. (1981). Evolutionary trees from DNA sequences: a maximum likelihood approach. J Mol Evol 17, 368-376.

Felsenstein, J. (1985). Confidence limits on phylogenies: an approach using the bootstrap. Evolution 39, 783-791.

Galtier, N., Gouy, M. \& Gautier, C. (1996). SEAVIEW and PHYLO_WIN: two graphic tools for sequence alignment and molecular phylogeny. Comput Appl Biosci 12, 543-548.

Godfroy, A., Lesongeur, F., Raguénès, G., Quérellou, J., Antoine, E., Meunier, J.-R., Guezennec, J. \& Barbier, G. (1997). Thermococcus hydrothermalis sp. nov., a new hyperthermophilic archaeon isolated from deep-sea hydrothermal vent. Int J Syst Bacteriol 47, 622-626.

Godfroy, A., Raven, N. D. H. \& Sharp, R. J. (2000). Physiology and continuous culture of the hyperthermophilic deep-sea vent archaeon Pyrococcus abyssi ST549. FEMS Microbiol Lett 186, 127-132.

Huber, R., Langworthy, T. A., König, H., Thomm, M., Woese, C. R., Sleytr, U. B. \& Stetter, K. O. (1986). Thermotoga maritima sp. nov. represents a new genus of uniquely extremely thermophilic eubacteria growing up to $90^{\circ} \mathrm{C}$. Arch Microbiol 144, 324-333.

Huber, R., Woese, C. R., Langworthy, T. A., Fricke, H. \& Stetter, K. O. (1989). Thermosipho africanus gen. nov., represents a new genus of thermophilic eubacteria within the "Thermotogales". Syst Appl Microbiol 12, 32-37.
Jeanthon, C., Reysenbach, A.-L., L'Haridon, S., Gambacorta, A., Pace, N. R., Glenat, P. \& Prieur, D. (1995). Thermotoga subterranea sp. nov., a new thermophilic bacterium isolated from a continental oil reservoir. Arch Microbiol 164, 91-97.

Lien, T., Madsen, M., Rainey, F. A. \& Birkeland, N. K. (1998). Petrotoga mobilis sp. nov., from a North Sea oil-production well. Int J Syst Bacteriol 48, 1007-1013.

Marmur, J. \& Doty, P. (1962). Determination of the base composition of deoxyribonucleic acid from its thermal denaturation temperature. J Mol Biol 5, 109-118.

Patel, B. K. C., Morgan, H. W. \& Daniel, R. M. (1985). Fervidobacterium nodosum gen. nov. and spec. nov., a new chemoorganotrophic, caldoactive, anaerobic bacterium. Arch Microbiol 141, 63-69.

Postec, A., Urios, L., Lesongeur, L., Ollivier, B., Querellou, J. \& Godfroy, A. (2005). Continuous enrichment culture and molecular monitoring to investigate the microbial diversity of thermophiles inhabiting deep-sea hydrothermal ecosystems. Curr Microbiol 50 (in press). doi:10.1007/s00284-004-4443-Z

Powers, E. M. (1995). Efficacy of the Ryu nonstaining $\mathrm{KOH}$ technique for rapidly determining gram reactions of food-borne and waterborne bacteria and yeasts. Appl Environ Microbiol 61, 3756-3758.

Raguénès, G., Pignet, P., Gauthier, G., Peres, A., Christen, R., Rougeaux, H., Barbier, G. \& Guezennec, J. (1996). Description of a new polymer-secreting bacterium from a deep-sea hydrothermal vent, Alteromonas macleodii subsp. fijiensis, and preliminary characterization of the polymer. Appl Environ Microbiol 62, 67-73.

Raguénès, G., Christen, R., Guezennec, J., Pignet, P. \& Barbier, G. (1997). Vibrio diabolicus sp. nov., a new polysaccharide-secreting organism isolated from a deep-sea hydrothermal vent polychaete annelid, Alvinella pompejana. Int J Syst Bacteriol 47, 989-995.

Raven, N., Ladwa, N. \& Sharp, R. (1992). Continuous culture of the hyperthermophilic archaeum Pyrococcus furiosus. Appl Microbiol Biotechnol 38, 263-267.

Saitou, N. \& Nei, M. (1987). The neighbor-joining method: a new method for reconstructing phylogenetic trees. Mol Biol Evol 4, 406-425.

Sharp, R. J. \& Raven, N. D. H. (1997). Isolation and growth of hyperthermophiles. In Applied Microbial Physiology: a Practical Approach, pp. 23-51. Edited by P. M. Rhodes \& P. F. Stanbury. Oxford: IRL Press.

Thompson, J. D., Higgins, D. G. \& Gibson, T. J. (1994). CLUSTAL W: improving the sensitivity of progressive multiple sequence alignment through sequence weighting, position-specific gap penalties and weight matrix choice. Nucleic Acids Res 22, 4673-4680.

Van Ooteghem, S. A., Beer, S. K. \& Yue, P. C. (2002). Hydrogen production by the thermophilic bacterium Thermotoga neapolitana. Appl Biochem Biotechnol 98-100, 177-189.

Wery, N., Lesongeur, F., Pignet, P., Derennes, V., Cambon-Bonavita, M. A., Godfroy, A. \& Barbier, G. (2001a). Marinitoga camini gen. nov., sp. nov., a rod-shaped bacterium belonging to the order Thermotogales, isolated from a deep-sea hydrothermal vent. Int J Syst Evol Microbiol 51, 495-504.

Wery, N., Moricet, J. M., Cueff, V., Jean, J., Pignet, P., Lesongeur, F., Cambon-Bonavita, M. A. \& Barbier, G. (2001b). Caloranaerobacter azorensis gen. nov., sp. nov., an anaerobic thermophilic bacterium isolated from a deep-sea hydrothermal vent. Int J Syst Evol Microbiol 51, 1789-1796.

Windberger, E., Huber, R., Trincone, A., Fricke, H. \& Stetter, K. O. (1989). Thermotoga thermarum sp. nov. and Thermotoga neapolitana occurring in African continental solfataric springs. Arch Microbiol 151, 506-512. 